\title{
Comorbidity of Migraine
}

\section{Migren ve Hastalık Birlikteliği}

\author{
Şebnem BIÇAKCI \\ Çukurova University, Medical Faculty, Department of Neurology, Adana, Turkey
}

\section{ABSTRACT}

Migraine is a common neurological disorder and can be severely disabling during attacks. The highest prevalence occurs between the ages of 25 and 55 years. Prior studies have found that migraine occurs together with other illnesses at a greater coincidental rate than is seen in the general population. These occurrences are called "comorbidities". To delineate the comorbidities of migraine is important, because it can help improve treatment strategies and the understanding of the possible pathophysiology of migraine. (Archives of Neuropsychiatry 2013; 50 Supplement 1: S14-S20)

Key words: Migraine, comorbidity

Conflict of interest: The authors reported no conflict of interest related to this article.

\section{Introduction}

Migraine is one of the common neurological diseases affecting $16.4 \%$ of our population ( $24.6 \%$ in women, $8.5 \%$ in men) (1). It is a significant cause of disability. However, the disability caused by the disease is not generally considered much (2). Currently, sufficient efforts are not made in many countries in the diagnosis and treatment. At the present time, many patients do not have sufficient awareness about migraine and the outcomes of migraine.

Comorbidity/disease association was described by Feinstein for the first time (3). It is defined as one or more diseases accompanying the primary disease. Migraine is observed in association with psychiatric and somatic diseases in a wide spectrum. Scher classifies this association as psychiatric, neurological, vascular, cardiac diseases and other diseases (4). Intensive studies conducted on this issue have established subtitles in this association spectrum. In understanding the pathophysiology of migraine comorbidity, the clinical picture is significant in terms of diagnosis and treatment. Recognition of this association may provide understanding of overlapping and confusing clinical pictures (for example, migraine and stroke association) or controlling of both conditions with a single treatment in events

\section{ÖZET}

Migren yaygın görülen, ataklar sırasında ağır fonksiyonel kayba neden olan nörolojik bir hastalıktır. Özellikte 25-55 yaşları arasında yüksek prevalansta görülmektedir. Bugüne kadar yapılan çalışmalar raslantısal olmanın dışında migren başağrılarının bazı hastalıklarla sık birlikteliğini vurgulamaktadır. Bu birliktelik "komorbidite/hastalık birlikteliği" olarak adlandırılmaktadır. Bu durum tedav stratejilerinin belirlenmesinde ve olası fizyopatolojik mekanizmaların anlaşımasında önem taşımaktadır. (Nöropsikiyatri Arşivi 2013; 50 Özel Sayı 1: S14-S20) Anahtar kelimeler: Migren, komorbitide

Çıkar çatışması: Yazarlar bu makale ile ilgili olarak herhangi bir çıkar çatışması bildirmemişlerdir.

triggered by migraine (for example, migrain-depression or migrainehypertension association). Migraine comorbidity is discussed on four basic mechanisms: presence of genetic and environmental factors, cause-effect relationship, mutual physiopathological background and completely accidental association. Absence of accidental associations is impossible in a chronic disease which is observed frequently like migraine. In this review, physiopathological conditions which are observed in association with migraine at the clinical base will be examined outside accidental association $(4,5)$.

\section{Migraine and Cardiovascular Diseases}

Many studies performed so far have shown the association of migraine and vascular problems. It is possible to evaluate this title as subtitles including migraine and stroke, subclinical brain matter lesions, coronary artery disease, hypertension and patent foramen ovale (PFO).

\section{Stroke}

The association of migraine and ischemic stroke (IS) has been known for long years based on case-control and cohort studies 
performed on this issue. In many case-control studies, migraine was considered a risk factor for stroke. The Collaborative Group for the Study of Stroke in Young Women compared patients with stroke who were hospitalized and population-based control groups. When compared with the population-based control group, the risk of stroke was found to be increased 2-fold in women with migraine, but the same result was not obtained in the hospital-based control group (6). Henrich and Horowitz showed a relation between migraine and stroke in hospital-based case-control studies, but similar results were not obtained, when stroke was adjusted for risk factors (7). Tzourio reported that the risk of stroke increased in women with migraine below the age of 45 years and this risk was increased with presence of smoking (8). In a longitudinal study, Henrich found the incidence of cerebral migraineous infarction to be $3,36 / 100000$ and this ratio was found to be $1.44 / 100000$ when individuals who carried other risk factors were eliminated (9).

In the study performed by Stang et al. in which the International Headache Society (IHS) diagnostic criteria were used, the odds ratio* $(\mathrm{OR})$ of the participants for recording of headache for a life time was calculated. According to this assessment the $\mathrm{OR}$ of stroke and migraine with aura was reported to be 5.46 , the $O R$ of transient ischemic attack and migraine was reported to be 4.28 and the OR of IS (ischemic stroke) and migraine was reported to be 2.81 (10).

The "Women's Health Study" data of Kurth et al. in a large series stand out as a significant source for this association (11). According to this study, 40.000 healthy female subjects aged 45 years of age and above who had no history of stroke or TIA with normal neurological examination were followed up for a long period of 9 years. Presence of migraine and aura was accepted as the statements of the subjects as yes or no. The OR of IS was determined to be 2.25 -fold in the subjects below the age of 55 years (11). According to subgroup analyses, it was found that the risk of IS increased in presence of active migraine with aura when cardiovascular risk factors including age, blood pressure, use of oral contraceptives $(\mathrm{OC})$ and cholesterol level were added, but these factors were not related with migraine without aura (11). When cardiovacular risk factors including smoking, alcohol, menstruel status, hormone levels, use of oral contraceptives and cholesterol level were added and when active migraine with aura was present, the risk of IS was found to be increased, but they were not found to be related with migraine without aura.

According to the results of the study performed by the same investigators in which 20084 male physicians between the ages of 40 and 84 years who were known to be healthy were followed up for 15.7 years, an increased risk was found between migraine and IS below the age of 55 years (RR:1.84). At more advanced ages, it was not found to be significant (12).

In the population-based study of Bigal et al. (American Migraine Prevalence and Prevention (AMPP)), a significant relation was found between migraine with aura and migraine in adult women and men (13).
Migraine is an independent risk factor for stroke. Aura, age and presence of other risk factors for stroke (smoking, use of OC, presence of systemic diseases which increase the risk, female gender) increase the risk. In women below the age of 45, the risk increases 9.03 -fold with smoking (8). Especially in women below the age of 45 years with migraine with aura, controlling of the present risk factors together with stroke, smoking and use of $\mathrm{OC}$ is important. When young women were excluded from the studies, migraine was not found to be a risk factor for ischemic stroke. At the age of 60 years, no difference was reported between the patients with migraine and the control group in terms of ischemic stroke. Patients with migraine do not carry a risk for hemorrhagic stroke.

\section{Subclinical white Matter Lesions}

In patients with migraine, white matter lesions were found with a rate of $6-46 \%$ on MR imagings. In patients with migraine with aura, subclinical infarction in the posterior circulation is observed with a 13.7-fold higher frequency (14). According to the case-control KAMERA study, lesions in the posterior circulation and subclinical white matter lesions were reported with a higher rate in patients with migraine and especially in patients with migraine with aura (15). No relation was found between white matter lesions and the clinical picture of migraine (16). Most infratentorial (88\%) infarctionlike lesions were shown in the localization of the cerebellar "borderzone" (17). The probable mechanism has been suggested to be hypoperfusion related with migraine attack and emboly (14). In the AGES-Reykjavik study conducted with middle-aged women who had long-term migraine with aura, cerebeallar infarction-like lesions which are observed in advanced ages were found with a 2,1-fold higher frequency (17).

\section{Hypertension}

Although migraine and hypertension are two conditions which are mentioned togehter frequently, studies performed on this issue have given contradictory results. In studies performed in normotensive subjects, no significant change was shown in measurements performed during active migrane attacks and even a negative correlation was shown. In these subjects, presence of diastolic hypotension was reported during attacks $(18,19,20,21$, 22). In the population-based study of Rasmussen and Olesen, no correlation was found (23). Subjects with migraine constitute a risk group in gestational hypertension (24). The GEM study and AMPP substudy showed a higher cardiovascular risk profile in patients with migraine with high cholesterol and blood pressure values 113 , 25). These data do not support the data obtained in the "Women's Health Study"(26). Further studies are needed to evaluate the relation between blood pressure and other cardiovascular risk factors and migraine. Accidental associations and the fact that migraine is a long-term chronic disease should be considered. In presence of hypertension or newly-developed hypertension, treatment options should be determined according to this variable. 


\section{Gene Polymorphysms}

In patients with migraine, 677C> metylenetetrahydrofolate reductase (MTHFR) gene and angiotensin converting enzyme (ACE) gene D/I polymorphisms were examined. According to the results of the "Women's Health Study", no relation with myocardial infarction (MI) was found (26). However, a major CV risk increase was observed with migraine with aura and gene polymorphism. No relation could be found between ACE D/l polymorphism and migraine of cardiovascular disease $(27,28)$.

\section{Cardiac Diseases}

Two controversial subtitles including coronary artery disease (CAD) and patent foramen ovale (PFO) will be evaluated under this title. Large-scale population-based studies on the relation between migraine and CAD have given controversial results. Rose et al. evaluated the risk of angina and coronary artery disease in patients with migraine with aura in 12409 participants in a follow-up period of 10 years. The prevalence risk for angina was found to be 3-fold higher, but no difference was found for a relation between CAD and migraine with aura $(29,30)$.

Kurth et al. (Women's Health Study) found a relation of migraine with aura not only with ischemic stroke but with all major cardiovascular diseases (Ml; angina, coronary revascularization) (26). In subjects with a high Framingan risk score, an association of active migraine with aura and MI was shown in presence of high cholesterol (31). In another study (Physicians' Health Study), it was emphasized that the risk of $\mathrm{Ml}$ increased by $42 \%$ in men with migraine and the risk of major cardiovascular disease increased by $24 \%$ when evaluated together with cardiovascular risk factors (12). In the AMPP substudy of Bigal et al., presence of an association with $\mathrm{MI}$ was reported in both migraine with aura and migraine without aura after cardiovascular risk factors were eliminated. (OR:2.86 1.85) (13). In patients with cardiac disease, migraine has a progressive or uncontrolled course. In fact, the point which should be considered during this natural course is treatment protocols. In patients with cardiovascular disease, no increase in the risk has been found with use of triptans which are the migraine-specific drug group used especially in attacks. However, physicians have a natural fear for these patients. These drugs should not be used in patients at advanced ages unless mandatory before necessary assessments are made (31).

In patients with migraine, PFO, atrial septal aneurism (ASA) and mitral valve prolapsus (MVP) are reported with a higher rate compared to the normal population. In presence of PFO, cryptogenic stroke, refractory hypoxemia, orthostatic oxygen desaturation, decompression sickness and migraine with aura are observed. In the normal population, the rate of PFO has been reported to be $27 \%$ in autopsy studies independent of race and gender. In patients with resistant migraine with aura, the rate of large PFO with rightleft shunt was found to be $37.7 \%$ on transthoracic ECHO. ASA was flound with a rate of $28.5 \%$ and MVP was found with a rate of $40 \%$ in patients with migraine with aura. It is assumed that the right-left shunt of this PFO can cause to paradoxal emboly and transition of vasoactive substances to the cerebral arterial system at high concentrations. In addition, possible mutual genetic background is considered (33). The results related with the effect of closure of PFO on attacks are controversial. According to the MIST (Migraine
Intervention with STARFlex Technology) study, no difference could be found in patients who underwent this procedure in the frequency of migraine attacks 6 months later compared to patients who did not underwent this procedure $(34,35)$.

\section{Small Artery Disese}

Migraine stands out as a significant part of the phenotype of many vasculopathies involving small arteries. These vasculopathies include CADASIL (cerebral autosomal dominant arteriopathy with subcortical infarcts) and leukoencephalopathy, cerebral leukodystrophy and retinal vasculopathy, hereditary infantile hemiparasia, retinal vasculopathy, cerebral retinal arteriolar tortuoisity and leukoencephalopathy. It is thought that small vessel diseases increase the risk of migraine by leading to direct vascular changes by way of endothelial dysfunction or via the neuronal pathway. This association is proposed because of mutual genetic factors on DNA gene $(36,37)$.

\section{Psychiatric Diseases}

Psychiatric diseases are observed commonly in association with migraine. This association is noted in depression, axiety disorder, bipolar disorder, phobia and suicide ideation and attempt (Tablo1) (37). This increases the progression and burden of the patient with migraine to a great extent. It has been thought that presence of serotonergic dysfunction, central sensitization and drug overuse might contribute to this association.

\section{Depression}

In the Zurich retrospecitve epidemiological cohort study, association of psychiatric disease was investigated in young

\begin{tabular}{|c|c|}
\hline Psychiatric Disease & Odds ratio"/ OR \\
\hline $\begin{array}{l}\text { Major depression } \\
\text { (Merikangas et al., 1990; Breslau et al., 2003) }\end{array}$ & $2.2-3.4$ \\
\hline $\begin{array}{l}\text { Bipolar spectrum } \\
\text { (Merikangas et al., 1990; Breslau et al., 1991) }\end{array}$ & $2.9-7.3$ \\
\hline $\begin{array}{l}\text { Anxiety } \\
\text { (Merikangas et al., 1990) }\end{array}$ & 2.7 \\
\hline $\begin{array}{l}\text { Panic disorder } \\
\text { (Merikangas et al ., 1990; Breslau et al., 2001) }\end{array}$ & $3.0-5.09$ \\
\hline $\begin{array}{l}\text { Diffuse anxiety disorder } \\
\text { (Merikangas et al ., 1990; McWilliams et al., 2004) }\end{array}$ & $3.9-5.3$ \\
\hline $\begin{array}{l}\text { Agoraphobia } \\
\text { (Merikangas et al., 1990) }\end{array}$ & 2.4 \\
\hline $\begin{array}{l}\text { Social phobia } \\
\text { (Merikangas et al ., 1990) }\end{array}$ & 3.4 \\
\hline $\begin{array}{l}\text { Suicide attempt } \\
\star * * \text { (Breslau, 1992) }\end{array}$ & 4.3 \\
\hline $\begin{array}{l}\text { ISuicide ideation **(Breslau, 1992; } \\
\text { Wang et al., 2009) }\end{array}$ & $1.8-24$ \\
\hline \multicolumn{2}{|c|}{$\begin{array}{l}\text { * Wang et al. Migraine comorbidity Frontiers in Neurology | Headache Medicine and Facial Pain } 2010 \\
(38,39,40,41,42)\end{array}$} \\
\hline
\end{tabular}


adults with migraine and a significant association was observed (OR:2,2) (39).

According to the results of the population-based studies in the perspective of bi-directional relation (migraine in depression and depression in migraine), the risk of new-onset migraine in patients with depression was found to be 2.8-3.5 and the risk of new-onset depression in patients with migraine was found to be 2.4-5.8 (39).

According to another population-based study performed using USA adult data, the rates of depression were assessed in presence of three painful conditions (migraine, arthritis and back pain); presence of clinical depression was confirmed in only $12.3 \%$ of the subjects who had no migraine and in $28.5 \%$ of the subjects with migraine (OR:2,8). In presence of psychological stress comorbidity, severe disruption in the quality of life was found in patients with migraine $(42,44)$. Tietjzen found somatic complications (OR:8.6) and major depressive state (OR: 25.1) with considerable high rates in chronic headache leading to disability. It has been reported that especially exposure to chronic stress is important in association of migraine and major depression (45).

\section{Diffuse Axiety Disorder}

The association of anxiety and migraine has been investigated in population-based and clinical studies. According to the results of these studies, diffuse anxiety disorder has been found with a high rate in migraine (OR:3.9-5.3). Presence of mutual environmental and genetic factors is emphasized $(46,47,48)$.

\section{Panic Disorder}

Its incidence in patients with migraine is controversial (40). According to the study of Breslau, it was found to be high. In a population-based study, the temporal relation was evaluated and no significant difference was found in terms of lifelong prevalence of panic disorder and its prevalence in other headaches. Panic disorder is observed frequently in all severe headaches. It has not been found to be specific to migraine (49).

\section{Suicide Ideation and Attempt}

Suicide ideation and attempt in young asults with a history of migraine with aura was reported by Breslau et al. for the first time as two successive presentations $(50,51)$. Wang et al. found a high rate of suicide ideation in adolescents with daily chronic headache (52). This association was not observed in patients with migraine without aura. Again, the same investigators found suicide ideation with a higher rate in adolescents aged 13-15 years with migraine with aura especially with a high frequency of headache $(<7$ days $/$ month) compared to the normal population (OR:1.69) (43).

\section{Bipolar Disorder}

There are few studies evaluating bipolar disorder in migraine. In two population-based studies, a significant association was found between migraine and bipolar disorder in young adults (OR:2.97.3). As a result of a pharmacoepidemiological study in which Norwegian prescription database was used, the $\mathrm{OR}$ was found to be 3,16 in men and 2.21 in women $(39,53)$.

\section{Epilepsy}

Association of migraine and epilepsy is controversial. According to the data obtained from studies, migraine is found with a high prevalence in epilepsy patients $(54,55,56,57,58,59)$. Sometimes presence of a mutual history including trauma, chronic episodic course, gastrointestinal autonomic findings, mood, behavior and consciouss changes and focal motor and sensory symptoms is noted between epilepsy and migraine. Both conditions may triger each other (epileptic seizures triggered by migraine or migraine attacks following epileptic seizures). The differential diagnosis is not very easy especially in the childhood. The prevalence of migraine was found to be $26-86 \%$ in patients with epilepsy (58). Especially migraine with aura is observed with a rate of $41.8 \%(25.8 \%$ in normal individuals). If the parents describe epilepsy, migraine is found with a rate of $24 \%$ in the child. Epilepsy was found with a rate of $5,9 \%$ in patients with migraine $(0,5 \%$ in normal individuals) (55). Epileptic seizures during migraine aura were found with a rate of $11.3-16.5 \%$ and these seizures are called migralepsy (54). No relation was found between the risk of migraine and early-onset epilepsy (epilepsy period) (58).

It is thought that the common ground in these two periodical diseases is genetic background $(60,61,62,63)$. Definition of migraine in two families with adult-onset myoclonic epilepsy and autosomal recessive idiopathic epilepsy supports this common genetics $(60,63)$. In a large Belgian family with association of occipital lobe epilepsy and migraine with visual aura, a connection locus was found on chromosome 9q21 and q222 involved in the association of migraine and epilepsy (61). Visual aura was defined in at least two members of 36 Finnish families and the same locus was found on genetic analysis (62).

\section{Vertigo}

Migraine and vertigo are two conditions which are observed frequently in the community. The lifelong prevalence is known to be $16 \%$ for migraine and $7 \%$ for vertigo. The rate of accidental association of these two conditions has been reported to be $1,1 \%$. However, recent epidemiological studies have shown that the actual rate of association is higher. As a result of studies with large series, migraine was found to be the cause of recurrent vertigo with a rate of $35 \%$ in pediatric patients and with a rate of $5 \%$ in adults. In these patients, abnormal vestibular function was found with a rate of $34-80 \%$, actual vertigo was found with a rate of $26 \%$, movement disorder was found with arate of $30-50 \%$ and idiopathic benign paroxismal positional vertigo was found with a rate of $18,8 \%$. As a result of clinical observations and epidemiological data, the concept of vertiginous migraine was presented. However, the diagnostic criteria of this title proposed by a group of investigators have not been included in the classification yet. They are planned to be included in the attachment in the third revised version of IHS. Debates are continuing on this issue $(64,65,66)$.

\section{Migraine and Movement Disorders}

The lifelong prevalence of migraine in Parkinson's disease was found to be $9.3-27.8 \%$ in case-control sudies. Remission was 
observed in migraine attacks in $2 / 3$ of the patients after disease symptoms started $(67,68)$.

Studies on Tourette syndrome are limited. Migraine attacks are observed with a 4-fold higher frequency compared to the normal population. Migraine attacks were reported with a rate of 39 in adults with Tourette syndrome and with a rate of $16 \%$ in children with Tourette syndrome. It is thought that obsessive compulsive disorder which is an element of the disease is not the underlying cause and it originates from different mechanisms $(68,69,70)$. It is proposed that disruption in the thalamocortical pathway and aminergic, genetic and psychiatric mechanisms are involved (68, $69,70)$.

In the beginning of the 1990s, uncontrolled studies showed that essential tremor (ET) which is the most common one among movement disorders was observed more frequently in patients with migraine compared to the normal population. Migraine was found with a rate of $36.5 \%$ in patients with essential tremor $(18 \%$ in the normal population) and essential tremor was found with a rate of $17.2 \%$ in patients with migraine. In the bi-directional relation between ET and migraine, it is thought that these two conditions share some common pathophysiological mechanisms and they arise from progressive tremogenic mechanisms rather than a vascular pathology. However, it is possible that this association is accidental considering that the frequencies of migraine and ET are high $(71,72)$.

\section{Sleep}

Sleep disorders have been found widely in migraine. These are not always explained with presence of depression and axiety. In one third of patients with migraine, difficulty in starting and continuing sleep was defined. More frequently defined sleep disorders in migraine include prolonged REM sleep latency, decrease in the REM time awakening index, somnambulism, narcolepsy and movement disorder in sleep. In a population-based study, all sleep symptoms examined were found with a significantly higher rate in children with migraine except for enuresis. Among parasomnias, only speaking during sleep, somnambulism and bruxisim were reported $(73,74,75)$. Migraine was found with a 2-4-fold higer rate in narcoleptic patients (74). Presence of sleep apnea and snoring were interpreted as poor prognostic markers in migraine. Increasing the quality of sleep has a positive effect on the prognosis (73).

\section{Restless Leg Syndrome}

Restless Leg Syndrome (RLS) is a common sensorimotor disease. The prevalence of RLS was found to be high in patients with migraine $(11.4 \%)(76)$. This association is emphasized more frequently according to the results of recent studies and the possible mechanism is proposed to be disruption in dopaminergic system function and iron metabolism (77). In patients with migraine and RLS, accompanying symptoms were found to have a more severe course (tinnitus, vertgio, disruption of the quiality of sleep). RLS affects daily life activities in patients with headache. No clear interpretation can be made on the effect of controlling RLS and increasing sleep quality on the frequency of migraine $(76,77,78,79)$.

\section{Chronic Pain}

According to the "The Nord-Trondelag Health Study" musculoskeletal pain was reported with a higher rate in patients with headache compared to patients without headache. Similar rates were found in migraine and non-migraine headaches. These ORs were found to be 1.9 for migraine headache and 1.8 for nonmigraine headache (80). Von Korrf defined headaches with the characteristics of migraine in patients with chronic spinal pain (OR:5.2). Similarly, the frequency of fibromyalgia was found to be $22-40 \%$ in patients with migraine $(81,82,83)$. In these patients, high rates of insomnia, reduction in the quality of life, more intensive mental stress were noted (81). Fibromyalgia was found with a higher rate in female patients with migraine compared to male patients with migraine (84).

Cutaneous allodynia is a clinical manifestation of central sensitization. Cutaneous allodynia was found in approximately $60 \%$ of 1413 patients with migraine during migraine attack. Cutaneous allodynia was defined in at least one region in $23 \%$ of these patients and in four or more regions in $9 \%$. In patients who described severe allodynia, the time of history of migraine was found to be longer compared to the other patients and axiety and depression symptoms and smoking were reported in association (85).

\section{Other Comorbid Conditions}

According to the results of the "Head Hunt" study, it was proposed that asthma and chronic bronchitis were found with a 1.5fold higher rate in migraine and non-migraine headaches and were related with the frequency of headache. In another study, it was found that diagnosis of new asthma was not different in patients with migraine compared to patients without migraine (OR:1.17). An independent relation is known to be present between allergic diseases and migraine $(86,87)$. The $\mathrm{OR}$ of migraine was found to be much higher $(1,6)$ in patients with irritable bowel syndrome compared to patients without irritable bowel syndrome (83). Celiac disease was found more frequently in patients with migraine (88).

The prevalence of migrain was found to be high in patients with vasculitis. It was reported that it arised from vascular, neuronal and endothelial cell dysfunction and was closely related with disease exacerbations. In patients with Lupus, any headache was found with a rate of $32-78 \%$ and the prevalence of isolated migraine was found to be $25-66 \%(88,89)$.

Conclusively, migraine is a complex chronic disease which may occasionally have a progressive course and which may be difficult to manage. Awarenes of comorbidities is important and directive especially in terms of physiopathology and treatment. comorbidities can be demonstrated with strong and well-structured epidemiological studies. New well-structured studies are needed in many titles which are still controversial.

\section{References}

1. Ertas M, Baykan B, Kocasoy Orhan E, Zarifoglu M, Karli N, Saip S, Onal $A E$, Siva A. One-year prevalence and the impact of migraine and tensiontype headache in Turkey: a nationwide home-based study in adults. $J$ Headache Pain 2012; 13:147-157. 
2. Andlin-Sobocki P, Jönsson B, Wittchen HU, Olesen J. Cost of disorders of the brain in Europe. Eur J Neurol 2005; 12(Suppl 1):1-27.

3. Feinstein $A$. The pre-therapeutic classification of co-morbidity in chronic disease. J Chronic Dis 1970; 23:455-468.

4. Scher Al, Bigal ME, Lipton RB. Comorbidity of migraine Curr Opin Neurol 2005; 18:305-310.

5. Jensen R, Stovner LJ . Epidemiology and comorbidity of headache. Lancet Neurol 2008; 7:354-361.

6. Collaborative Group for the Study of Stroke in Young Women. Oral contraseptives and stroke in young women. JAMA 1975; 281:718-722.

7. Henrich JB, Horowitz RI. A controlled study of ischemic stroke risk in migraine patients.J Clin Epidemiol 1989; 42:773-780.

8. Tzourio $C$, Iglesias $S$, Hubert JB, Visy JM, Alpérovitch A, Tehindrazanarivelo A, Biousse V, Woimant F, Bousser MG. Migraine and risk of ischaemic stroke: a case-control study. BMJ 1993; 31:289-292.

9. Henrich JB, Sandercock PAG, Warlow CP, Jones LN. Stroke and migraine in the Oxfordshire Community Stroke Project. J Neurol 1986; 233:257-262.

10. Stang PE, Carson AP, Rose KM, Mo J, Ephross SA, Shahar E, and Szklo $M$. Headache, cerebrovascular symptoms, and stroke: the Atherosclerosis Risk in Communities Study. Neurology 2005; 64:1573-1577.

11. Kurth T, Slomke MA, Kase CS, Cook NR, Lee IM, Gaziano JM, Diener $\mathrm{HC}$, Buring JE. Migraine, headache, and the risk of stroke in women: a prospective study. Neurology 2005; 64:1020-1026.

12. Kurth T, Gaziano JM, Cook NR, Bubes V, Logroscino G, Diener HC, Buring JE. Migraine and risk of cardiovascular disease in men. Arch. Intern. Med 2007; 167:795-801.

13. Bigal ME, Kurth T, Santanello N, Buse D, Golden W, Robbins M, and Lipton RB. Migraine and cardiovascular disease: a population-based study. Neurology 2010; 74:628-635.

14. Kruit MC, van Buchem MA, Hofman PA, Bakkers JT, Terwindt GM, Ferrari MD, Launer LJ. Migraine as a risk factor for subclinical brain lesions. JAMA 2004; 291:427-434.

15. Kruit MC, Launer LJ, Ferrari MD, van Buchem MA. Infarcts in the posterior circulation territory in migraine. The population-based MRI CAMERA study. Brain 2005; 128:2068-2077.

16. Over F, Bıcakcı S, Sarıca Y, Sertdemir Y. Beyaz Cevher Lezyonları ve Migren. Türk Nörol Derg 2007; 13:201-206.

17. Scher Al, Gudmundsson LS, Sigurdsson S, Ghambaryan A, Aspelund T, Eiriksdottir G, van Buchem MA, Gudnason V, Launer LJ. Migraine headache in middle age and late-life brain infarcts. JAMA 2009; 24:2563-2570.

18. Seçil Y, Unde C, Beckmann YY, Bozkaya YT, Ozerkan F, Başoğlu M. Blood pressure changes in migraine patients before, during and after migraine attacks. Pain Pract 2010; 10:222-227.

19. Wiehe M, Fuchs SC, Moreira LB, Moraes RS, Fuchs FD. Migraine is more frequent in individuals with optimal and normal blood pressure: a population-based study. J Hypertens 2002; 20:1303-1306.

20. Tzourio $C$, Gagnière $B$, El Amrani $M$, Alpérovitch $A$, and Bousser MG. Relationship between migraine, blood pressure and carotid thickness. A population-based study in the elderly. Cephalalgia 2003; 23:914-920.

21. Franceschi M, Colombo B, Rossi P, Canal N. Headache in a populationbased elderly cohort. An ancillary study to the Italian Longitudinal Study of Aging (ILSA). Headache 1997; 37:79-82.

22. Cirillo M, Stellato D, Lombardi C, De Santo NG, Covelli V. Headache and cardiovascular risk factors: positive association with hypertension. Headache 1999; 39:409-416.

23. Rasmussen BK, Olesen J. Symptomatic and nonsymptomatic headaches in a general population. Neurology 1992; 42:1225-1231.

24. Scher Al, Terwindt GM, Picavet HS, Verschuren WM, Ferrari MD, Launer LJ. Cardiovascular risk factors and migraine: the GEM population-based study. Neurology 2005; 64:614-620.

25. Kurth T, Gaziano JM, Cook NR, Logroscino G, Diener HC, Buring JE. Migraine and risk of cardiovascular disease in women. JAMA 2006; 296:283-291.

26. Scher Al, Terwindt GM, Verschuren WM, Kruit MC, Blom HJ, Kowa $\mathrm{H}$, Frants RR, van den Maagdenberg AM, van Buchem M, Ferrari MD,Launer LJ. Migraine and MTHFR C677T genotype in a population-based sample. Ann Neurol 2006; 59:372-375.

27. Schürks M, Zee RY, Buring JE,Kurth T. ACE D/I polymorphism, migraine, and cardiovascular disease in women. Neurology 2009; 72:650-656.
28. Schürks M, Rist PM, Bigal ME, Buring JE, Lipton RB, Kurth T Migraine and Cardiovasculer disease: systematic review and meta- analysis. BMJ 2009; 1:17-24.

29. Rose KM, Carson AP, Sanford CP, Stang PE, Brown CA, Folsom AR, Szklo $M$. Migraine and other headaches: associations with Rose angina and coronary heart disease. Neurology 2004; 63:2233-2239.

30. Kurth T, Schürks M, Logroscino G, Gaziano JM, Buring JE. Migraine, vascular risk, and cardiovascular events in women: prospective cohort study. BMJ 2008; 337:1-9.

31. Tietjen EG. Migraine and ischaemic heart disease and stroke: potential mechanisms and treatment implications. Cephalalgia 2007; 27:981-987.

32. Dowson A, Mullen MJ, Peatfield R, Muir K, Khan AA, Wells C, Lipscombe SL, Rees T, De Giovanni JV, Morrison WL, Hildick-Smith D, Elrington G, Hillis WS, Malik IS, Rickards A. Migraine Intervention With STARFlex Technology (MIST) trial:a prospective, multicenter, double-blind, sham-controlled trial to evaluate the effectiveness of patent foramen ovale closure with STARFlex septal repair implant to resolve refractory migraine headache. Circulation 2008; 18;117:1397-1404.

33. Schwedt TJ, Demaerschalk BM, Dodick DW. Patent foramen ovale and migraine: a quantitative systematic review. Cephalalgia 2008; 28:531-540.

34. Fazio G, Ferro G, Carità P, Lunetta M, Gullotti A, Trapani R, Fabbiano A, Novo G, Novo S. The PFO anatomy evaluation as possible tool to stratify the associated risks and the benefits arising from the closure. Eur $\mathrm{J}$ Echocardiogr 2010; 11:488-491.

35. Agostoni E, Rigamonti A. Migraine and small vessel diseases. Neurol Sci 2012; 33(Suppl 1):51-54.

36. Terwindt GM, Haan J, Ophoff RA, Groenen SM, Storimans CW, Lanser JB, Roos RA, Bleeker-Wagemakers E M, Frants RR, and Ferrari MD. Clinical and genetic analysis of a large Dutch family with autosomal dominant vascular retinopathy, migraine and Raynaud's phenomenon. Brain 1998; 121;303-316.

37. Wang SJ, Chen PK, Fuh JL. Comorbidities of migraine. Front Neurol 2010; 23:1-16.

38. Merikangas KR, Angst J, Isler H. Migraine and psychopathology. Results of the Zurich cohort study of young adults. Arch Gen Psychiatry 1990; 47:849853.

39. Breslau N, Schultz LR, Stewart W F, Lipton R B, and Welch KMA. Headache types and panic dis $\neg$ order. Neurology 2001; 56:350-354.

40. Breslau N, Lipton RB, Stewart WF, Schultz LR, Welch KM.: Comorbidity of migraine and depression: investigating potential etiology and prognosis. Neurology 2003; 60:1308-1312.

41. McWilliams L A, Goodwin RD, and Cox B J. Depression and anxiety associated with three pain conditions: results from a nationally representative sample. Pain 2004; 111:77-83.

42. Wang J, Fuh JL, Juang K D, and Lu SR. Migraine and suicidal ideation in adolescents aged 13 to 15 years old. Neurology 2009; 72:1146-1152.

43. Breslau N, Davis GC, Schultz LR, and Peterson EL. Migraine and major depression: A longitudinal study. Headache 1994; 34:387-393.

44. Tietjen GE, Brandes JL, Digre KB, Baggaley S, Martin V, Recober A, Geweke LO, Hafeez F, Aurora SK, Herial NA, Utley C, Khuder SA. High prevalence of somatic symptoms and depression in women with disabling chronic headache. Neurology 2007; 68:134-140.

45. Antonaci F,Nappi G, Galli F, Manzoni GC, Calabresi P, Costa A. Migraine and psychiatric comorbidity: a review of clinical findings. J Headache Pain 2011; 12:115-125.

46. Mercante JP, Peres MF, Bernik MA. Primary headaches in patients with generalized anxiety disorder. J Headache Pain 2011; 12:331-338.

47. Beghi E, Bussone G, D'Amico D,Cortelli P, Cevoli S,Manzoni GC, Torelli P, Tonini MC, Allais G, De Simone R, D'Onofrio F, Genco S,Moschiano F, Beghi M, Salvi S.. Headache, anxiety and depressive disorder: The HADAS study. J Headache Pain 2010; 11:141-150.

48. Smoller JW, Pollack MH, Wassertheil-Smoller S, Barton B, Hendrix SL, Jackson RD, Dicken T, Oberman A, Sheps DS; Women's Health Initiative Investigators. Prevalence and correlates of panic attacks in postmenopausal women: results from an ancillary study to the Women's Health Initiative Arch Intern Med 2003; 163:2041-2050.

49. Breslau N, Davis GC, Andreski P. Migraine, psychiatric disorders, and suicide attempts: an epidemiologic study of young adults. Psychiatry Res 1991; 37:11-23. 
50. Breslau N. Migraine, suicidal ideation, and suicide attempts. Neurology 1992; 42:392-395.

51. Wang SJ, Juang KD, Fuh JL, Lu SR. Psychiatric comorbidity and suicide risk in adolescents with chronic daily headache. Neurology 2007; 68:1468-1473.

52. Oedegaard KJ, Dilsaver SC, Hundal O, Riise T, Lund A, Akiskal HS, Fasmer OB. Are Migraine and Bipolar Disorders Comorbid Phenomena? Findings From a Pharmacoepidemiological Study Using the Norwegian Prescription Database. J Clin Psychopharmacol 2011; 31:734-739.

53. Marks DA, Ehrenberg BL. Migraine-related seizures in adults with epilepsy, with EEG correlation. Neurology 1993; 43:2476-2483.

54. Bigal ME, Lipton RB, Cohen J, Silberstein SD. Epilepsy and migraine. Epilepsy Behav 2003; 4(Suppl 2):13-24.

55. Karaali-Savrun F, Göksan B, Yeni SN, Ertan S, Uzun N. Seizure-related headache in patients with epilepsy. Seizure 2002; 11:67-69.

56. Nuyen J, Schellevis FG, Satariano WA, Spreeuwenberg PM, Birkner MD, van den Bos GA, Groenewegen PP. Comorbidity was associated with neurologic and psychiatric diseases: a general practice-based controlled study. J Clin Epidemiol 2006; 59:1274-1284.

57. Toldo I, Perissinotto E, Menegazzo F, Boniver C, Sartori S, Salviati L Clementi M,Montagna P, Battistella PA. Comorbidity between headache and epilepsy in a pediatric headache center. J Headache Pain 2010; 11:235-240.

58. Striano P, Belcastro V, Verrotti A, Parisi P. Epilepsi “Comorbidity” between epilepsy and headache/migraine: the other side of the same coin. $J$ Headache Pain 2011; 12:577-578.

59. Baykan B, Madia F, Bebek N, Gianotti, S, Güney Al, Cine N, Bianchi A, Gökyiği, A, Zara F. Autosomal recessive idiopathic epilepsy in an inbred family from Turkey: identification of a putative locus on chromosome 9q3233. Epilepsia 2004; 45:479-487.

60. Deprez L, Peeters K, Van Paesschen W, Claeys KG, Claes L R, Suls A, Audenaert D, Van Dyck T, Goossens D, Del-Favero J, and De Jonghe P. Familial occipitotemporal lobe epilepsy and migraine with visual aura: linkage to chromosome 9q. Neurology 2007; 68:1995-2002.

61. Tikka-Kleemola P, Artto V, Vepsäläinen S, Sobel EM, Räty S, Kaunisto MA., Anttila V, Hämäläinen E, Sumelahti ML, Ilmavirta M, Färkkilä M, Kallela M, Palotie $A$, and Wessman MA visual migraine aura locus maps to 9q21-q22. Neurolog 2010; 74:1171-1177.

62. Saka E, Saygi S. Familial adult onset myoclonic epilepsy associated with migraine. Seizure 2000; 9:344-346.

63. Neuhauser $H$, Leopold $M$, von Brevern $M$, Arnold, G,and Lempert The interrelations of migraine,vertigo, and migrainousvertigo. Neurology 200; 56:436-441.

64. Lempert T, Neuhauser $\mathrm{H}$. Epidemiology of vertigo, migraine and vestibular migraine. J Neurol 2009; 256:333-338.

65. Lempert T, Olesen J, FurmanJ, Waterston J, Seemungal B, Carey J. Bisdorff A, Versino M, Evers S, Newman-Toker D. Vestibular migraine: diagnostic criteria. J. VestibRes 2012; 22:167-172.

66. Barbanti P, Fabbrini G, Vanacore N, Rum A, Lenzi GL, Meco G, Cerbo $\mathrm{R}$ Dopamine and migraine: does Parkinson's disease modify migraine course? Cephalalgia 2000; 20:720-723.

67. Barbanti P, Fabbrini G Migraine and the extrapyramidal system. Cephalalgia 2002; 22:2-11.

68. Kwak C, Vuong KD, Jankovic J. Migraine headache in patients with Tourette syndrome. Arch Neurol 2003; 60:1595-1598

69. Barbanti P, Fabbrini G. Migraine and Tourette syndrome. Arch Neurol 2004; 61:606-607.
70. Duval C, Norton L. Tremor in patients with migraine. Headache 2006; 46:1005-1010.

71. Barbanti P, Fabbrini G, Aurilia C, Defazio G, Colosimo C, Berardelli A. No association between essential tremor and migraine: a case-control study. Cephalalgia 2010; 30:686-689.

72. Cevoli S, Giannini G, Favoni V, Pierangeli G, Cortelli P. Migraine and sleep disorders Neurol Sci 2012; 33(Suppl 1):43-46.

73. Dahmen N, Kasten M, Wieczorek S, Gencik M, Epplen JT, Ullrich B. Increased frequency of migraine in narcoleptic patients: a confirmatory study. Cephalalgia 2003; 23:14-19.

74. Arruda MA, Guidetti V, Galli F, Albuquerque RC, Bigal ME. Childhood periodic syndromes: a population-based study. Pediatr Neurol 2010; 43:420-424.

75. Rhode AM, Ho"sing VG, Happe S, Biehl K, Young P, Evers S. Comorbidity of migraine and restless legs syndrome: a case-control study. Cephalalgia 2007; 27:1255-1260.

76. d'Onofrio F, Bussone G, Cologno D, Petretta V, Buzzi MG, Tedeschi G, Bonavita V, Cicarelli G. Restless legs syndrome and primary headaches: a clinical study. Neurol Sci 2008; 29(Suppl 1):169-172.

77. Young WB, Piovesan E, Biglan KM. Restless legs syndrome and druginduced akathisia in headache patients. CNS Spectr 2003; 8:450-456.

78. Chen PK, Fuh JL, Chen SP, Wang SJ. Association between restless legs syndrome and migraine. J Neurol Neurosurg Psychiatry 2010; 81:524-528.

79. Hagen K, Einarsen C, Zwart JA, Svebak S, Bovim G. The co-occurrence of headache and musculoskeletal symptoms amongst 51050 adults in Norway. Eur J Neurol 2002; 9:527-533.

80. Peres MF, Young WB, Kaup A0, Zukerman E, and Silberstein SD. Fibromyalgia is common in patients with transformed migraine. Neurology 2001; 57:1326-1328.

81. Peres MF, Zukerman E, Young WB, and Silberstein SD. Fatigue in chronic migraine patients. Cephalalgia 2002; 22:720-724.

82. Cole JA, Rothman KJ, Cabral HJ, Zhang Y, Farraye FA. Migraine, fibromyalgia, and depression among people with IBS: a prevalence study. BMC Gastroenterol 2006; 8:6-26.

83. Tommaso M, Federici A, Serpino C, Vecchio E, Franco G, Sardaro M Delussi M, Livrea P. Clinical features of headache patients with fibromyalgia comorbidity. J Headache Pain 2011; 12:629-638.

84. Tietjen GE, Brandes JL, Peterlin BL, Eloff A, Dafer RM, Stein MR, Drexler E, Martin VT, Hutchinson S, Aurora SK, Recober A, Herial NA, Utley C, White L, Khuder SA. Allodynia in migraine: association with comorbid pain conditions. Headache 2009; 49:1333-1344.

85. Aamodt AH Stovner, LJ, Langhammer A, Hagen K,and Zwart JA. Is headache related to asthma, hay fever, and chronic bronchitis? The HeadHUNT Study. Headache 2007; 47:204-212.

86. Ozge A, Ozge C, Oztürk C, Kaleagasi H, Ozcan M, Yalçinkaya DE, Ozveren $\mathrm{N}$, Yalçin FThe relationship between migraine and atopic disorders-the contribution of pulmonary function tests and immunological screening. Cephalalgia 2006; 26:172-179.

87. Alehan F, Ozçay F, Erol I, Canan 0, Cemil T. Increased risk for coeliac disease in paediatric patients with migraine. Cephalalgia 2008; 28:945-949.

88. Lessa B, Santana A, Lima I, Almeida JM, Santiago M.. Prevalence and classification of headache in patients with systemic lupus erythematosus. Clin Rheumatol 2006; 25:850-853.

89. Bicakci S, Ozbek S, Bicakci K, Aslan K, Kara B, Sarica Y. Recurrent headache and MRI findings in systemic lupus erythematosus. J Natl Med Assoc 2008; 100:323-326. 